\title{
Dose response relationships of insulin hypoglycaemia and gastric acid in man
}

\author{
J. H. BARON \\ From the Department of Surgery, Royal Postgraduate Medical School, London, W12
}

SUMMARY Fourteen studies of gastric acid secretion in a basal hour and in the two hours after a single intravenous injection of soluble insulin $(0.01$ to $0.40 \mathrm{units} / \mathrm{kg})$ were performed in a healthy man. The peak acid output after insulin (measured as the two consecutive 15-minute samples giving the highest acid output) was significantly correlated with the lowest concentration of blood glucose, the fall in blood glucose, the rate of fall of blood glucose, and the maximum fall of blood glucose in any 15 minutes. Peak acid outputs after insulin were similar over the range $0 \cdot 1$ to $0 \cdot 2 \mathrm{units} / \mathrm{kg}$, and greater than at lower or higher doses.

These results are contrary to the accepted assumption that insulin-stimulated acid secretion is an 'all-or-none' phenomenon. They support instead the hypothesis that insulin hypoglycaemia provides a quantitative glycopenic stimulus producing quantitative vagal acid response. Extreme hypoglycaemia, below about $15 \mathrm{mg} / 100 \mathrm{ml}$ of blood glucose, inhibits insulin-stimulated acid secretion.

Certain assumptions about the insulin test have been widely held (Roholm, 1930; Hollander, Jemerin, and Weinstein, 1942) in the 40 years since intravenous insulin was found to be an hypoglycaemic stimulus of gastric acid secretion (Simici, Popescu, and Diculesco, 1927). These assumptions are that the acid response is an 'all-or-none' phenomenon which is (1) initiated when the blood sugar falls to a threshold value of $40-50 \mathrm{mg} / 100 \mathrm{ml}$; (2) not related to the degree of hypoglycaemia below this threshold; (3) not dependent on the fall in blood sugar; and (4) not related to the rate of fall of blood sugar.

Hollander (1946) later suggested the insulin test as a method of recognizing completeness of vagal denervation of the stomach in man, and his test is used universally, despite lack of agreement on technique and interpretation. However, Clark, Curnow, Murray, Stephens, and Wyllie (1964) suggested that a fall in blood sugar of 30 to 50 $\mathrm{mg} / 100 \mathrm{ml}$ evoked a maximum response regardless of the initial fasting level, whilst Demand, Gross, and Berg (1968) found that the rate of increase of acid output was significantly corReceived for publication 11 February 1970. related with the concentration of blood glucose at the time of maximum gastric secretory response.

Almost all investigations of this problem have been done in series of different individuals and it is clear that the relationship between blood sugar 욱 and gastric acid needs further examination by tests of different doses of insulin in the same individual.

\section{Method}

The subject, a healthy male aged 37 years and without dyspepsia, fasted overnight. The right nostril and throat were sprayed with $3 \%$ lignocaine in isotonic saline. A plastic nasogastric tube (Rayx Porges, 14 or $16 \mathrm{~mm}$ circumference) was $\stackrel{\odot}{\stackrel{\circ}{~}}$ positioned by fluoroscopy in the most dependent $\stackrel{\mathbb{Q}}{2}$ part of the body of the stomach, and a plastic cannula inserted in a vein in the forearm. The 8 stomach was emptied and the tube connected to continuous pump suction, interrupted by manual syringe suction. After a basal hour (four 15- $\frac{\sigma}{\rightleftharpoons}$ minute periods of collection) soluble insulin 
(Boots, insulin BP) was given as a rapid single intravenous injection over the range 0.01-0.40 units/kg body weight, and eight more 15 -minute collections were made. The volume, $p \mathrm{H}$, and titratable acidity of each specimen of gastric juice were measured by methods already described (Baron, 1963). Venous blood was taken before the insulin injection, and $15,30,45,60,90$, and 120 minutes after the insulin to determine the whole blood glucose by a glucose oxidase AutoAnalyzer technique (Wincey and Marks, 1961). Although capillary blood glucose may more closely resemble the glucose concentration reaching the glycoreceptors in the brain responsible for vagal stimulation, venous blood was collected in these studies, so that potassium, cortisol, and growth hormone could be measured as well. These results will be reported separately. Gillespie, Gillespie, and Kay (1969) found no significant difference between arterial and venous blood sugar concentrations during insulin tests.

There were 14 tests with insulin in the range $0.01-0.4 \mathrm{u} / \mathrm{kg}$ (Table I). In the one test in which $0.01 \mathrm{u} / \mathrm{kg}$ insulin was given, gastric acid was not stimulated at all. The analyses of the relationships between acid secretion and blood glucose changes are based on 13 tests.

\section{Results}

In order to make maximum use of the data and to compare the results with the many variables which have been described, extensive analyses have been carried out to examine the relationships between acid secretion and changes in the concentration of blood glucose.

The following variables of acid secretion have

\begin{tabular}{|c|c|c|c|c|c|c|c|c|}
\hline \multirow[t]{2}{*}{$\begin{array}{l}\text { Insulin Dose } \\
(u / k g)\end{array}$} & \multirow[t]{2}{*}{ No. of Tests } & \multicolumn{7}{|c|}{$\begin{array}{l}\text { No. of Tests in which Peak Half-hour Acid } \\
\text { Occurred in Each Period (min) }\end{array}$} \\
\hline & & $0-30$ & $15-45$ & $30-60$ & $45-75$ & $60-90$ & $75-105$ & $90-120$ \\
\hline $\begin{array}{l}0 \cdot 01 \\
0 \cdot 03 \\
0 \cdot 05 \\
0 \cdot 1 \\
0 \cdot 15 \\
0 \cdot 2 \\
0 \cdot 25 \\
0 \cdot 3 \\
0 \cdot 4\end{array}$ & $\begin{array}{l}1 \\
1 \\
1 \\
2 \\
2 \\
2 \\
2 \\
1 \\
2\end{array}$ & & & $\begin{array}{l}1 \\
1\end{array}$ & $\begin{array}{l}2 \\
1\end{array}$ & 2 & 2 & $\begin{array}{l}1 \\
1\end{array}$ \\
\hline $\begin{array}{l}\text { Lowest blood } \\
11-20 \\
21-30 \\
31-40\end{array}$ & $(\mathrm{mg} / 100 \mathrm{ml})$ & & & $\begin{array}{l}2 \\
1\end{array}$ & $\begin{array}{l}2 \\
1\end{array}$ & 2 & $\begin{array}{l}1 \\
1\end{array}$ & $\begin{array}{l}2 \\
1\end{array}$ \\
\hline $\begin{array}{l}\text { Maximum fal } \\
<20 \\
21-30 \\
31-40 \\
>40\end{array}$ & od glucose (mg & & & $\begin{array}{l}1 \\
2\end{array}$ & $\begin{array}{l}1 \\
2\end{array}$ & $\begin{array}{l}1 \\
1\end{array}$ & $\begin{array}{l}1 \\
1\end{array}$ & $\begin{array}{l}1 \\
2\end{array}$ \\
\hline All tests & & & & 3 & 3 & 2 & 2 & 3 \\
\hline
\end{tabular}

Table I Timing of peak acid output in relation to insulin dose and changes in blood glucose been examined: (1) The basal acid output, calculated as the sum of the four basal 15-minute periods. (2) The peak acid output calculated as the sum of the two highest consecutive 15-minute collections, multiplied by two, and expressed as m-equiv/hour (Baron, 1962 and 1963). (3) The maximum acidity, which was the highest concentration of titratable acidity achieved, expressed as m-equiv/litre. (4) The maximum increase in acidity being the maximum acidity minus the mean acidity in the half hour before insulin, and expressed as m-equiv/litre.

Four variables of blood glucose were also examined. These were: (1) the lowest blood glucose, being the lowest value observed after the injection of insulin, and expressed as $\mathrm{mg} / 100 \mathrm{ml}$. (2) The maximum fall of blood glucose, being the difference between the initial blood glucose and the lowest blood glucose (expressed as $\mathrm{mg} / 100 \mathrm{ml}$ ). (3) The rate of maximum fall of blood glucose, being the quotient of maximum fall of blood glucose divided by the time (in minutes) for blood glucose to fall from an initial value to its lowest concentration (expressed as $\mathrm{mg} / 100 \mathrm{ml}$ per minute). (4) The maximum fall of blood glucose in any 15 -minute period expressed as $\mathrm{mg} / 100 \mathrm{ml}$.

Each of these four absolute values of blood glucose has also been expressed as a percentage of the initial, fasting blood glucose, thus giving eight different methods of expressing change in blood glucose.

\section{BASAL SECRETION}

There was no significant correlation between basal acid output and the blood glucose at the end of the basal hour $(r=0.02, P=0.47)$.

\section{SECRETION AFTER INSULIN}

In the first half hour there was a slight and insignificant decrease in acid output. After this initial half hour of nearly constant secretion, volume, titratable acidity, and acid output increased to a peak and then declined to basal levels within two hours of the injection of the insulin. In one test, which was prolonged, acid output remained low in the third hour, and there was no suggestion of a late response after 120 minutes (Fig. 1). Concentrations of blood glucose decreased to their lowest level at $\mathbf{3 0}$ minutes after the insulin injection and rose again towards basal levels within 2 hours. In only two tests was the lowest blood glucose delayed until 45 minutes.

\section{TIMING OF PEAK ACID OUTPUT AND DOSE} RELATIONSHIP

The peak half hour of acid secretion in the two hours after insulin was evenly distributed during the period 30-120 minutes, and showed no relationship to the dose of insulin, the lowest blood glucose, or the maximum fall in blood glucose 

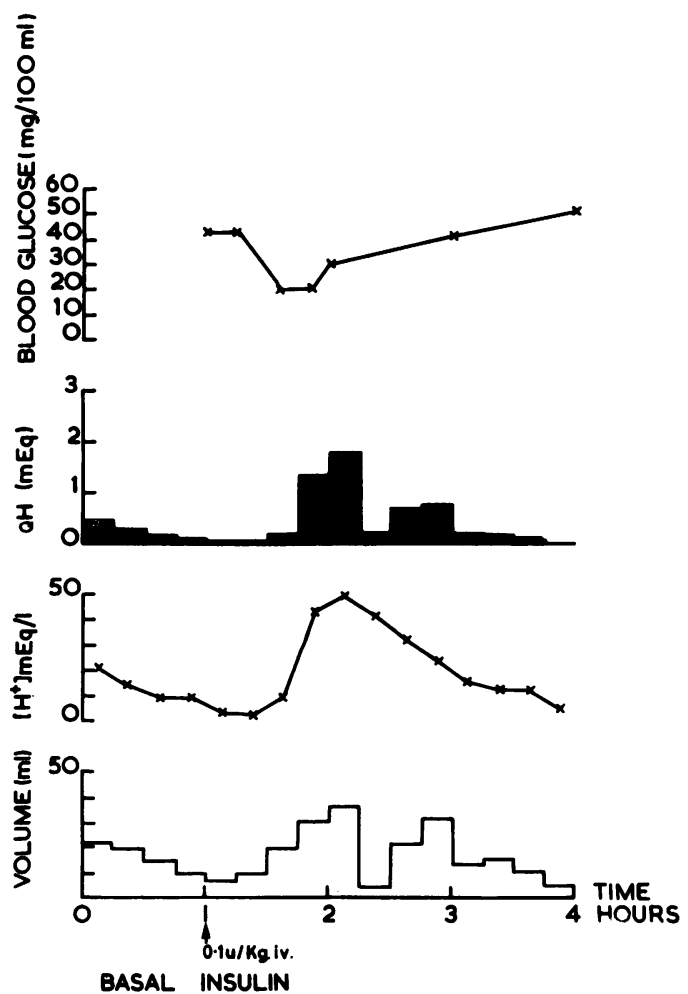

Fig. 1 Blood glucose and gastric secretory volume, concentration and output of acid in the one hour before, and three hours after, intravenous insulin.
(Table I). The usual hypoglycaemic symptoms and signs appeared 20-30 minutes after insulin was injected but lessened with repeated testing.

PEAK ACID OUTPUT

The graph of the relationship of peak acid output $\frac{\vec{\sigma}}{\overparen{2}}$ after insulin and the lowest blood glucose sugges- $\varrho$ ted that acid output increased as blood glucose levels became lower; the slope of the straight line $\vec{\circ}$ fitted to this data was significantly different from zero (Fig. 2a). However, further inspection of the $\vec{\sigma}$ data shown in Fig. 2a suggested that there mighto be a systematic biphasic acid secretory response to changes in the lowest blood glucose, with peak $\overrightarrow{.}$ acid output rising as blood glucose falls, but $\vec{\circ}$ declining when lowest blood glucose falls belowio about $15 \mathrm{mg} / 100 \mathrm{ml}$.

Some evidence for these trends was provided by음 fitting quadratics to the data (Fig. 2b): the residual variation of the data about the quadratics $O$ was significantly less than that about the straight $\stackrel{\circ}{\circ}$ line. Although the quadratic is the most convenient curve for testing whether a trend is linear, many other alternative curves would fit the data as well $\underline{\varphi}$ or even better. For example, straight lines can be. fitted separately for the two phases of the data, stimulation and inhibition, and these lines fit the data very well (Fig. 3). There is no statistical basis for choosing between these various ways of ${ }_{0}^{0}$ describing the data, and the choice must rest on $\stackrel{\otimes}{\otimes}$

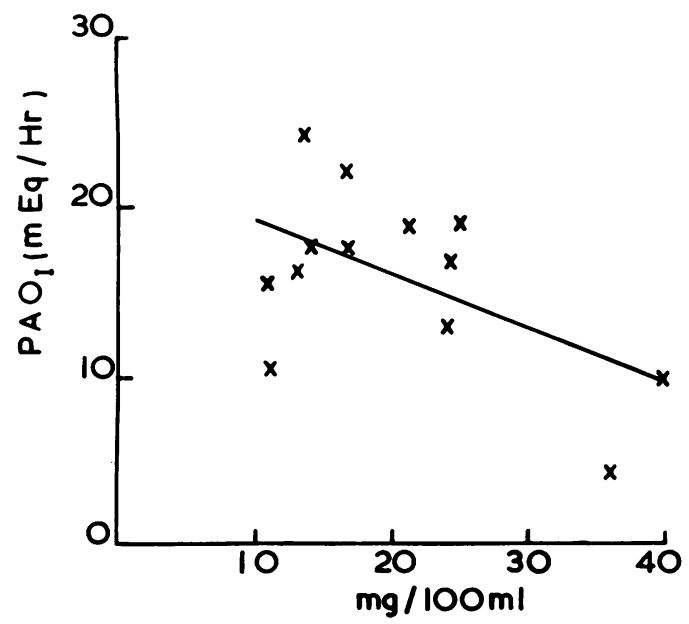

Fig. 2a Linear correlations $(y=a+b x)$ of peak acid output after insulin with lowest blood glucose expressed as $\mathrm{mg} / 100 \mathrm{ml}(r=-0.56, \mathrm{P}=0.02)$ and as a percentage of initial blood glucose $(r=-0.59, \mathrm{P}=0.02)$ in all 13 tests in which gastric acid was stimulated. 
the plausibility of the relationships and their descriptive usefulness. With a small number of observations there is a good case for just reporting the actual data and this policy has been adopted with the rest of the results of acid output.

With increase in the maximum fall of blood glucose (the second of the four variables of blood glucose examined), peak acid output after insulin

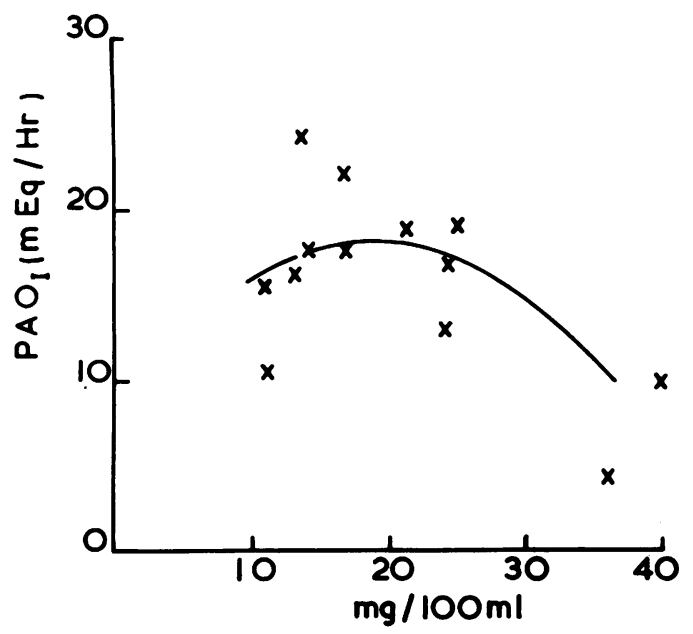

Fig. 2b Quadratic correlations $\left(y=a+b_{1} x+b_{2} x^{2}\right)$ of peak acid output after insulin with lowest blood glucose expressed as $\mathrm{mg} / 100 \mathrm{ml}\left(\mathrm{Pb}_{2}=0.00000003\right)$ and as a percentage of initial blood glucose $\left(\mathrm{P} b_{2}=\right.$ $0.00000003)$ in all 13 tests.

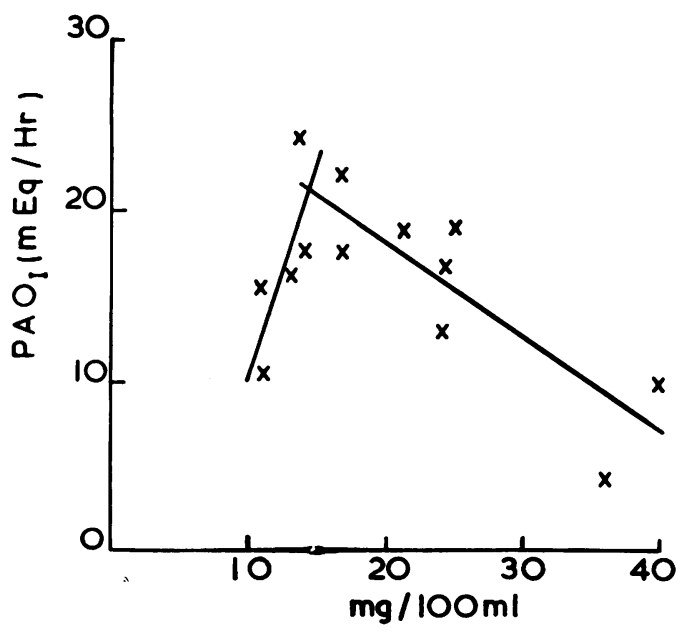

Fig. 3 Linear correlations of peak and output after insulin with lowest blood glucose over the range in which hypoglycaemia is associated with stimulation of gastric acid secretion $(r=-0.84, P=0.001$; $r=0.91, P=0.0001$ ) and the range in which extreme hypoglycaemia is associated with partial inhibition of acid secretion $(r=0.75, P=007 ; r=0.85$, $P=0.03)$. increased, but again there was a situation in which large falls in blood glucose led to inhibition of acid output (Fig. 4a). The graphs for the rate of maximum fall of blood glucose (third variable) (Fig. 4b), and maximum fall of blood glucose in any 15 minutes (fourth variable) (Fig. 4c) showed similar trends. In all but one of the eight measurements of changes in blood glucose, a quadratic

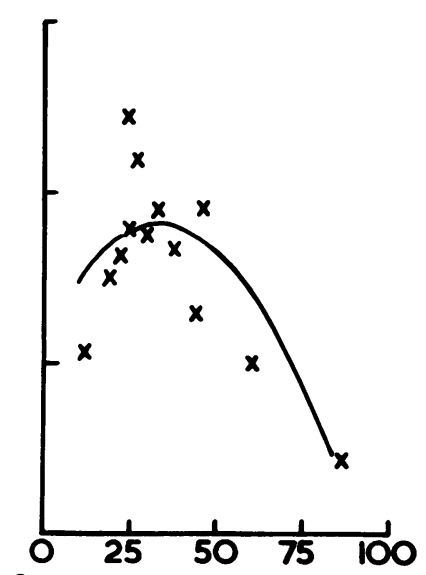

AS $\%$ OF NITIAL BLOOD GLUCOSE

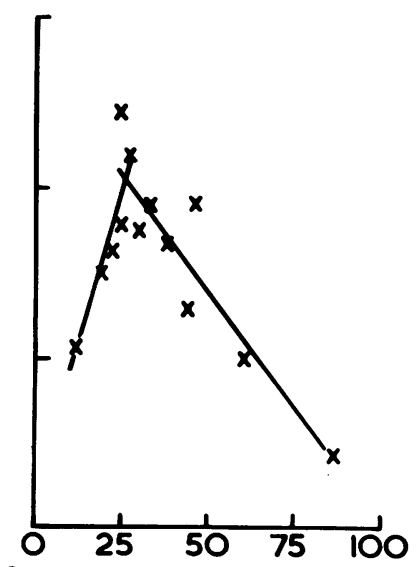

AS \% OF NITIAL BLOOD GLUCOSE 


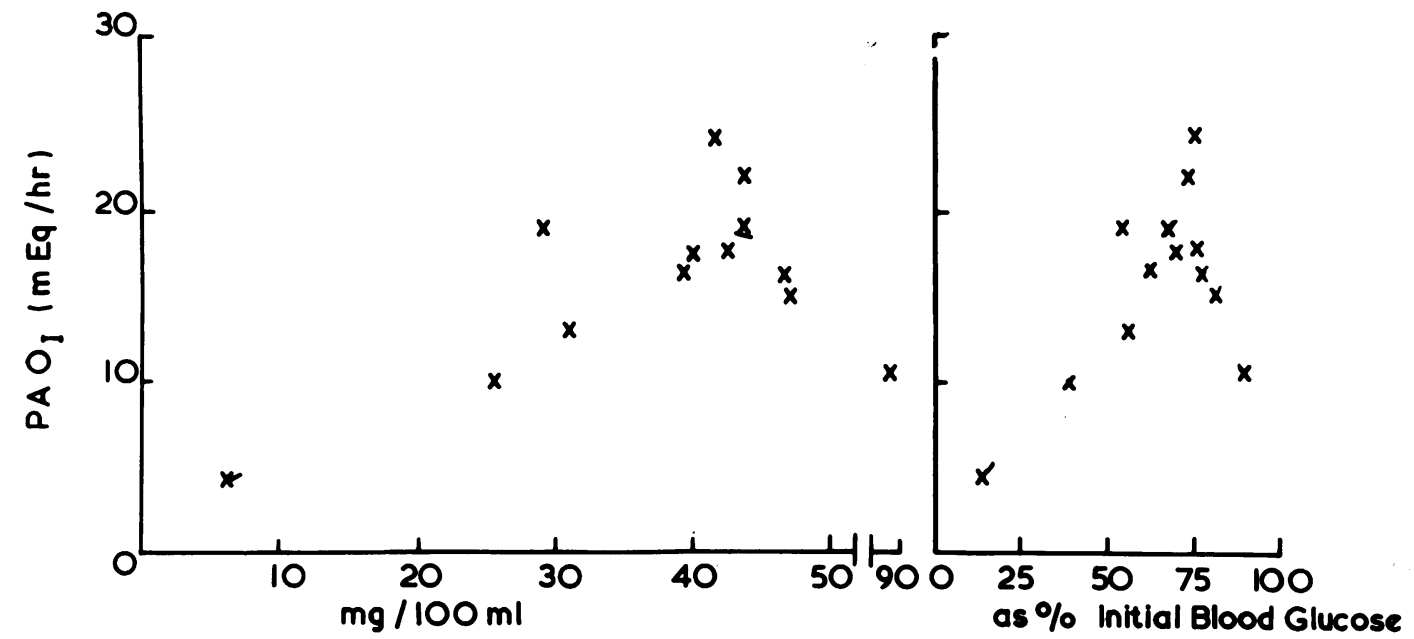

Fig. 4a Peak and output after insulin and maximum fall in blood glucose.
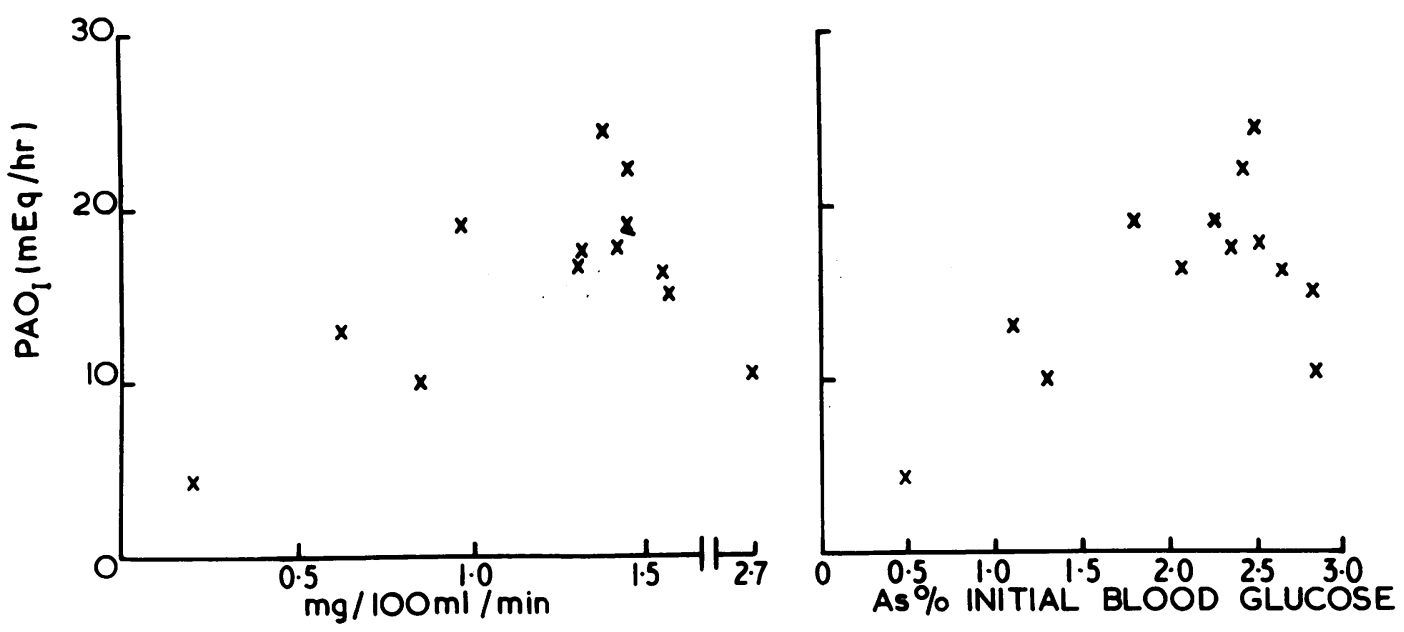

Fig. 4b Peak and output after insulin and rate of maximum fall in blood glucose.
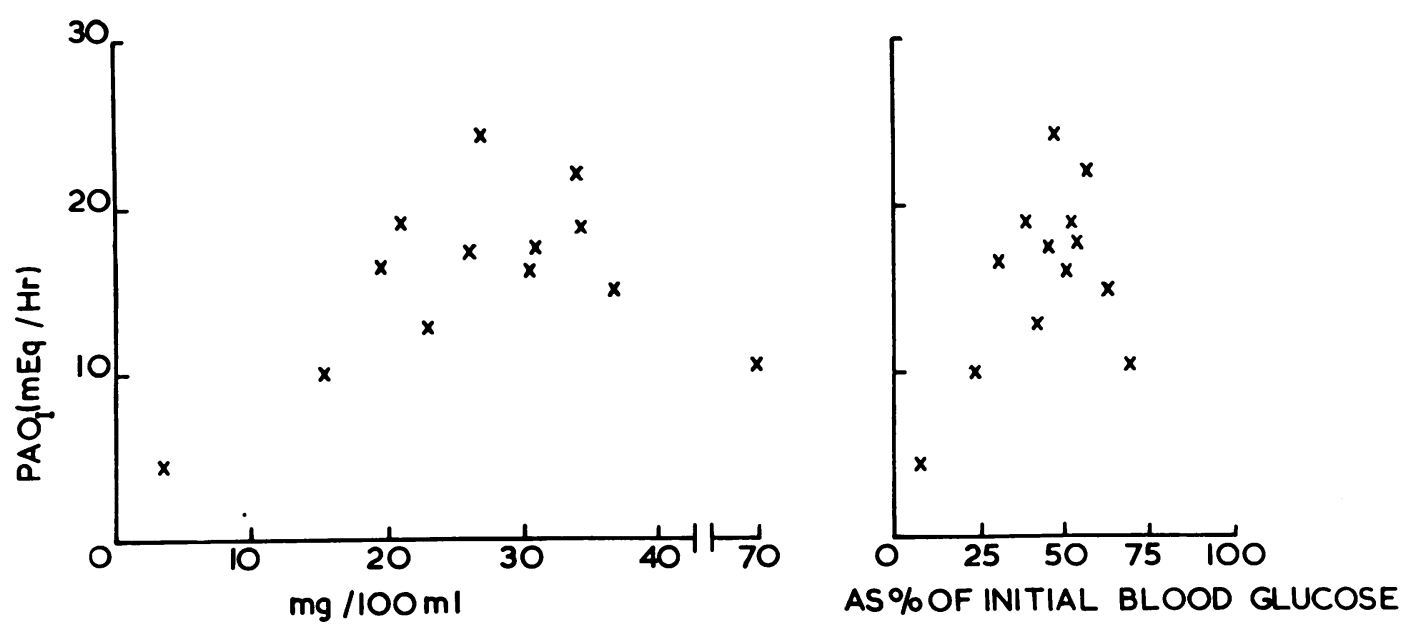

Fig. 4c Peak acid output after insulin and maximum fall in blood glucose in any 15 minutes. 
curve provided a better fit to the data than a straight line, thus providing evidence that the trends were not linear; however, it is also clear from the graphs that many of these measurements are highly correlated with each other.

\section{TITRATAB LE ACIDITY}

The maximum acidity and increase in acidity were related in a very similar fashion to that of peak acid output to measurements of blood glucose.

\section{INSULIN DOSE AND BLOOD GLUCOSE}

There were of course statistically significant correlations (Table II) between the dose of insulin and all the different expressions of changes in blood glucose described above. The larger doses of insulin prolonged the hypoglycaemia so that

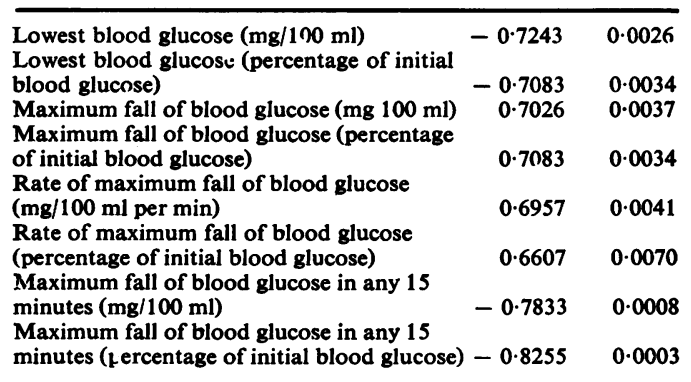

Table II Linear correlations of insulin dose and changes of blood glucose in 13 tests two hours after the injection of insulin blood glucose was also inversely correlated with the dose of insulin.

\section{INSULIN DOSE AND ACID OUTPUT}

Peak acid outputs after insulin increased over the range $0 \cdot 01-0 \cdot 1$ units $/ \mathrm{kg}$, were similar over the range $0 \cdot 1-0 \cdot 2$ units $/ \mathrm{kg}$, and then tended to fall (Fig. 5a). The relationship with insulin dose and acid output over the whole two hours was similar (Fig. 5b). Similar curves were obtained if the acid output after insulin was expressed for the periods $0-60,60-120,30-90$, or $30-120$ minutes, or as peak acid output minus basal acid output.

\section{Discussion}

These results are not compatible with the accepted assumption (Bachrach, 1953) that gastric acid secretion after intravenous insulin is an 'all-ornone' response to a blood sugar below $50 \mathrm{mg} / 100$ $\mathrm{ml}$, and suggest instead a relationship between insulin dose, hypoglycaemia, and acid secretion by the stomach. The hypoglycaemia-sensitive cephalic centres (Jögi, Ström, and Uvnäs, 1949) may respond to the lowest blood glucose concentration achieved, the absolute fall, the maximum rate of fall. or the maximum fall in any unit time. The hypoglycaemic stimulus might be either an absolute change in blood glucose concentration or a proportion of initial concentration of blood

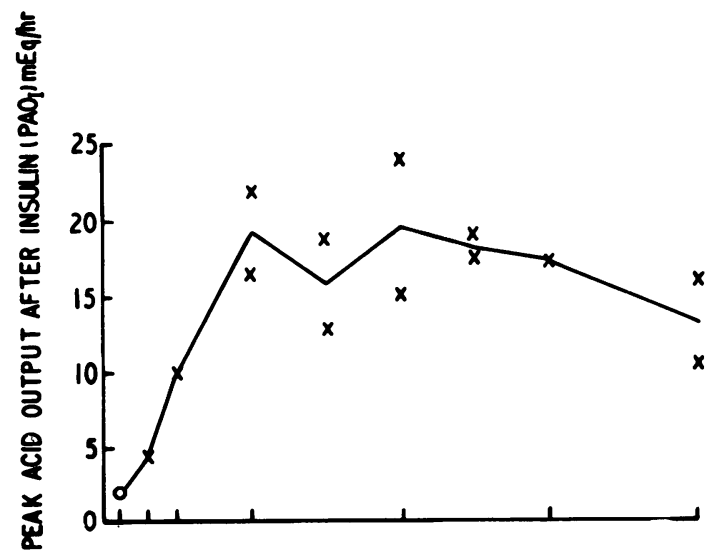

Fig. 5a Peak acid output after insulin and dose of intravenous insulin in all 14 tests.

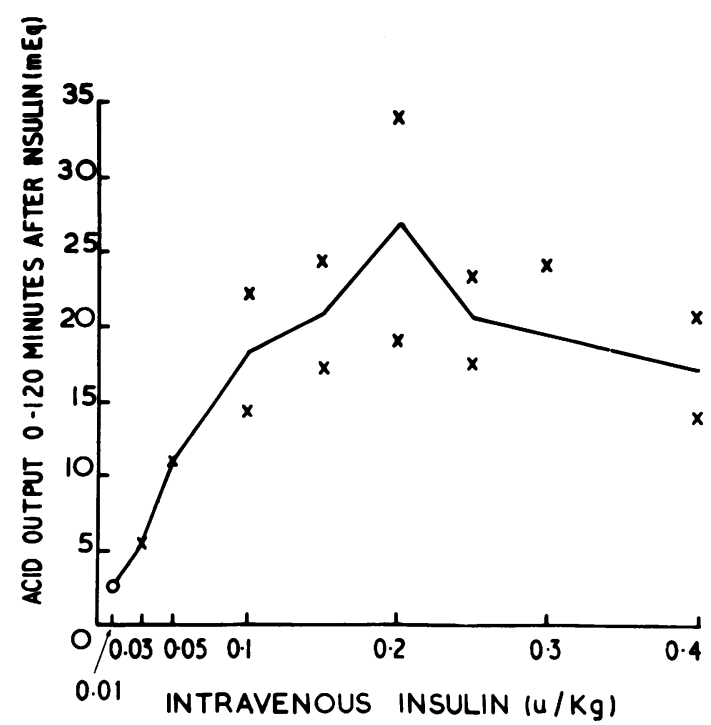

Fig. 5b Acid output in the two hours after insulin and dose of intravenous insulin in all 14 tests. 
glucose before the stimulus. Inhibition may occur in association with extreme hypoglycaemia. The present data are compatible with all these possibilities. There are three major phenomena to be considered and they will be discussed separately.

\section{AN HYPOGLYCAEMIC THRESHOLD FOR THE INITIATION OF ACID STIMULATION}

The smallest dose of insulin $(0.03 \mathrm{u} / \mathrm{kg})$, which elicited an acid response from the subject produced a blood glucose as low as $36 \mathrm{mg} / \mathrm{ml}$. An even smaller dose $(0.01 \mathrm{u} / \mathrm{kg})$ produced a blood glucose of $58 \mathrm{mg} / 100 \mathrm{ml}$ but no acid stimulation. It was not possible from these limited studies to determine a precise hypoglycaemic threshold for initiation of acid secretion, but various estimates have been made ranging from $18-67 \mathrm{mg} / 100 \mathrm{ml}$ blood sugar (Stempien, Lee, and Dagradi, 1968) to $50-85 \mathrm{mg} / 100 \mathrm{ml}$ blood sugar (Hiles, 1947). Although most authors accept the threshold hypothesis, there have been suggestions 'that the vagal stimulation resulted more from a rapid decline in blood sugar than fromits actual value at any one time' (Hiles, 1947), or that 'a falling blood sugar may be sufficient for stimulation regardless of the rate or depth of that fall' (Stempien et al, 1968). However, the results in diabetic humans (Kalk and Meyer, 1932) and dogs (Kemp, Herrera, Isaza, and Eisenberg, 1968a) seem conclusive evidence for the hypothesis of a threshold blood glucose for initiation of acid secretion, and against the hypotheses of initiation by fall or rate of fall of blood glucose.

It seems reasonable to conclude from these studies that when the blood glucose falls, acid secretion is initiated at a certain threshold, and that a fall of blood glucose which does not reach this threshold, however rapid and even if the value is as large as several hundred $\mathrm{mg} / 100 \mathrm{ml}$, will not initiate gastric secretion. Although there does not seem to be any universal threshold for blood sugar in man or dog, the human threshold appears to be $\vec{\circ}$ between 33 and $73 \mathrm{mg} / 100 \mathrm{ml}$ (Demand et al, 1968), but may not be the same in the same individual from day to day. This threshold is below the range of blood glucose during normal activities, and there was no correlation between basal acid output and blood glucose in the present series. It is, therefore, unlikely that variations in spontaneous interdigestive basal secretion in man could be due to variations in blood sugar.

INSULIN DOSE, HYPOGLYCAEMIA, AND ACID OUTPUT

The results presented have shown a quantitative relationship between insulin hypoglycaemia and gastric acid output. This relationship has not previously been described, and the literature has therefore been reviewed critically to explain these differences.

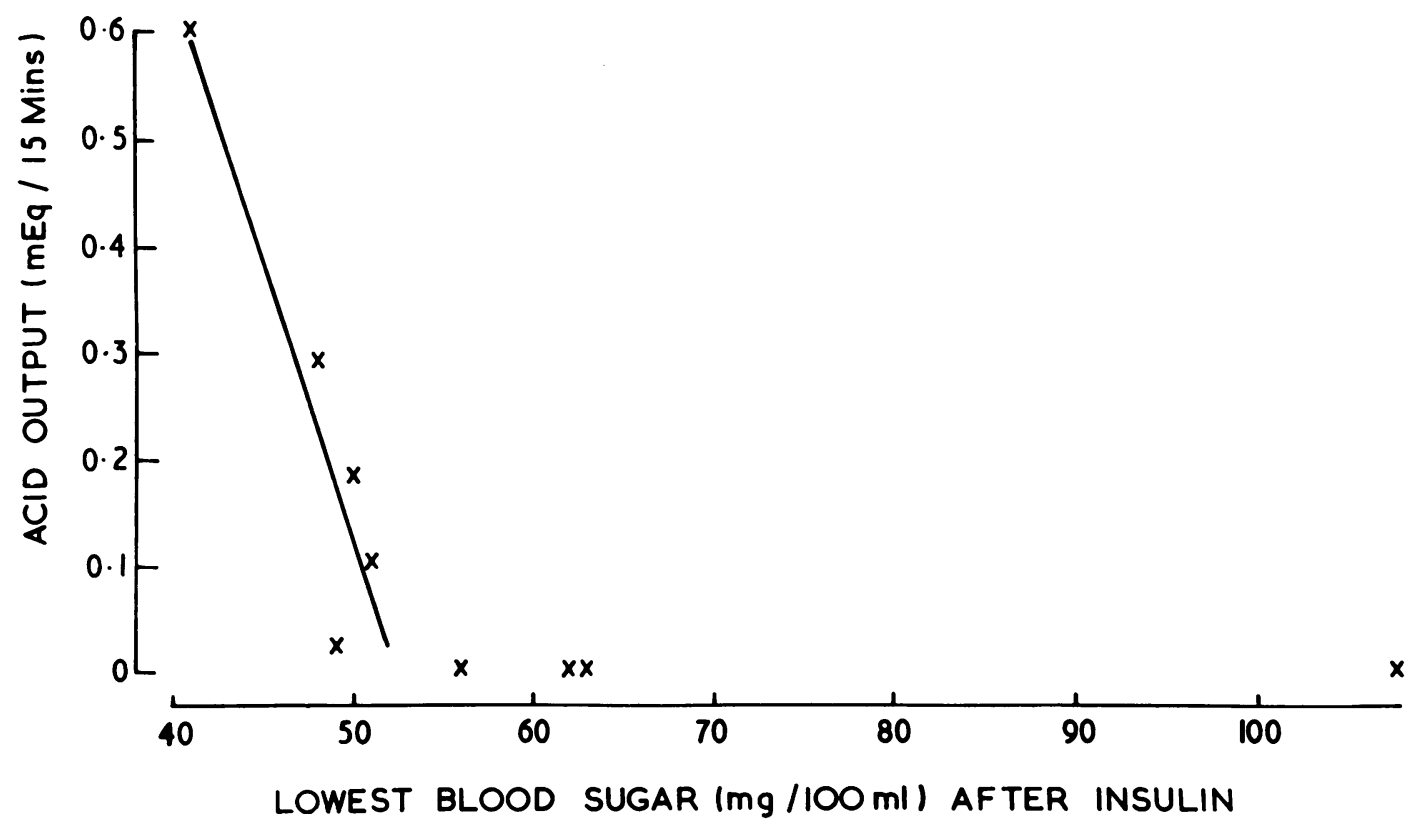

Fig. 6 Acid output and lowest blood sugar, recalculated from the data of dog 77 of Jemerin et al (1942) $(r=-0.917 ; \mathrm{P}=0.014)$. 


\section{Animal data}

Hollander et al (1942), in their original study, concluded that 'It is impossible, however, to establish any quantitative relation between the magnitude of the insulin dosage or the hypoglycaemia on the one hand, and the volume-rate of secretion or the acidity on the other'. However, Jemerin, Hollander, and Weinstein (1942) claimed 'a rough parallel between the degree of hypoglycaemia and the magnitude of response was obtained in this animal'. This discrepancy may be related to Hollander's group having measured volume and acidity separately and omitted to calculate their product, acid output. Their data on dog 77 have therefore been recalculated (Fig. 6); there is a significant inverse linear correlation of gastric acid output with the lowest blood sugar concentration, similar to the results in the present paper (Fig. 2a). Similarly, recalculation of the data of Metys and Ronský (1959) suggests an inverse linear correlation (similar to Figs. 2a and 6) of acid output with the lowest blood sugar concentration $(n=6$, $r=-0.69, P=0.066$ ).

The most recent and apparently definitive studies of insulin hypoglycaemia in the dog (Davis and Brooks, 1962 and 1963; Davis, Brooks, and Robert, 1965; Brooks, 1967) claimed that the authors had confirmed the old 'all-or-none' law, although they failed to consider that acid response after single parenteral injections of drugs in man or dog should be analysed in terms of peak acid output (Marks, Komarov, and Shay, 1960; Baron, 1962 and 1963; Makhlouf, 1968) irrespective of the timing of peak acid output (Baron, 1968 and 1969). Recalculation of the data of Davis and his co-workers suggests that the acid changes are correlated with the blood sugar changes, and thus the acid changes are correlated with the insulin dose.

A dose-response relationship for vagally stimulated gastric acid was suggested for 2-D-deoxyglucose which is thought to stimulate the cephalic centres by the production of intracellular glycopenia, without reduction of glucose concentration in the extracellular fluid (Hirschowitz and Sachs, 1965; Eisenberg, Emas, and Grossman, 1966). Hirschowitz (1966) therefore deduced that insulin would be expected to show a similar dose-acid response relationship if to the observed acid output was added the amount of acid which insulin had inhibited at the same time. Hirschowitz and Sachs (1967) were able to demonstrate a significant correlation between the degree of hypoglycaemia and pepsin output, but not with acid output.

\section{Human data}

These are summarized in Table III. The results in the present paper suggest that acid secretion once

\begin{tabular}{|c|c|c|c|c|c|}
\hline Source & Drug & Dose & Route & Findings & Conclusion \\
\hline Roholm (1930) & Insulin & 12 units & Intravenously & $\begin{array}{l}\text { No correlation between the } \\
\text { lowest, the fall or the rate of fall } \\
\text { of blood sugar and the increase } \\
\text { in, or maximum, acidity. }\end{array}$ & $\begin{array}{l}\text { 'All-or-none' } \\
\text { relationship }\end{array}$ \\
\hline Ihre (1938) & Insulin & 16 units & Intravenously & $\begin{array}{l}\text { Acid output after } 20 \text { units not } \\
\text { more than after } 16 \text { units. Gastric } \\
\text { stimulation not related to } \\
\text { hypoglycaemia. }\end{array}$ & $\begin{array}{l}\text { 'All-or-none' } \\
\text { relationship }\end{array}$ \\
\hline $\begin{array}{l}\text { Bachrach (1949) quoted by } \\
\text { Bachrach and Bachrach (1967) }\end{array}$ & Insulin & $\begin{array}{l}0 \cdot 1,0 \cdot 2,0 \cdot 4 \\
\mathbf{u} / \mathbf{k g} \text { in same } \\
\text { patient }\end{array}$ & Intravenously & $\begin{array}{l}\text { Similar acidities after each of } \\
\text { these three doses (secretory } \\
\text { volume and acid output not } \\
\text { reported). }\end{array}$ & $\begin{array}{l}\text { 'All-or-none' } \\
\text { relationship }\end{array}$ \\
\hline Brooke (1949) & Insulin & $\begin{array}{l}10 \text { units } \\
0 \cdot 1 \mathrm{u} / \mathbf{k g}\end{array}$ & Intravenously & $\begin{array}{l}\text { No correlation between acid } \\
\text { response and fall or rate of fall } \\
\text { of blood sugar }\end{array}$ & $\begin{array}{l}\text { 'All-or-none' } \\
\text { relationship }\end{array}$ \\
\hline Sharick and Campbell (1951) & Insulin & $2 \cdot 2 \mathrm{u} / \mathrm{kg}$ & $\begin{array}{l}\text { Sub- } \\
\text { cutaneously }\end{array}$ & $\begin{array}{l}\text { No correlation between lowest } \\
\text { blood sugar and acid response. }\end{array}$ & $\begin{array}{l}\text { 'All-or-none' } \\
\text { relationship }\end{array}$ \\
\hline Clark et al (1964) & Insulin & 15 units & $\begin{array}{l}\text { Sub- } \\
\text { cutaneously }\end{array}$ & $\begin{array}{l}\text { In Fig. } 2 \text { a clear linear correlation } \\
\text { can be seen between insulin- } \\
\text { stimulated acid (as } \% \text { histamine- } \\
\text { stimulated) and maximum fall } \\
\text { of blood sugar. }\end{array}$ & $\begin{array}{l}\text { Maximum acid response } \\
\text { evoked by fall in blood } \\
\text { sugar of } 30-50 \mathrm{mg} / 100 \\
\text { ml }\end{array}$ \\
\hline Aylett (1965) & Tolbutamide & $100 \mathrm{mg}$ & Intravenously & $\begin{array}{l}\text { No correlation between blood } \\
\text { glucose and gastric secretion. }\end{array}$ & $\begin{array}{l}\text { 'All-or-none' } \\
\text { relationship }\end{array}$ \\
\hline Demand et al (1968) & Insulin & $0.09 \mathrm{u} / \mathbf{k g} / \mathrm{hr}$ & Intravenously & $\begin{array}{l}\text { Significant correlation between } \\
\text { rate of increase of acid output } \\
\text { and the absolute blood glucose } \\
\text { concentration at the maximum } \\
\text { of secretory stimulation but no } \\
\text { correlation with the insulin dose, } \\
\text { the absolute or relative blood } \\
\text { glucose at the onset of secretion, } \\
\text { or the rate of fall of blood glucose. }\end{array}$ & $\begin{array}{l}\text { 'All-or-none' } \\
\text { relationship }\end{array}$ \\
\hline Gillespie et al(1969) & Insulin & 20 units & Intravenously & $\begin{array}{l}\text { No correlation between blood } \\
\text { sugar change and acid response. }\end{array}$ & $\begin{array}{l}\text { 'All-or-none' } \\
\text { relationship }\end{array}$ \\
\hline
\end{tabular}

Table III The relationship between hypoglycaemia and gastric acid in man 
initiated after insulin hypoglycaemia is a quantitative vagal acid response in response to a quantitative glycopenic stimulus. It seems clear that previous reports, which have almost consistently claimed an 'all-or-none' response, have been almost exclusively based on studies of different subjects or animals. In the few studies where the same animal has been studied on more than one cccasion, recalculation of the data produced complete agreement with the interpretation of the human data of the present study.

The graphs of the correlation of acid output with lowest blood sugar (Figs. 2 and 6) are mirrored by the dose-response curves of peak acid output and insulin dose (Fig. 5a). However, the scatter of points along the line in Fig. 5 is considerable, presumably because the reproducibility of the insulin test is poorer than for other gastric near-maximal stimuli. For example, the coefficient of variation of 25 duplicate measurements of peak acid output after 0.15 units $/ \mathbf{k g}$ insulin was $16 \%$ (Hubel, 1966) as compared with $8 \%$ after an augmented histamine test (Baron, 1963 ), or $9 \%$ after pentagastrin (Baron, 1969). The imprecision of this relationship of acid output and insulin dose is understandable if 'the dose of insulin required to produce a given degree of hypoglycaemia cannot be predicted, because it varies not only in different individuals (man or animal) but also in the same individual from day to day' (Bachrach, 1953).

\section{INHIBITION OF GASTRIC SECRETION AFTER INSULIN}

In the present study there was no significant inhibition in the first half hour after insulin, but acid output was apparently increasingly inhibited at extreme hypoglycaemia, below about 15 $\mathrm{mg} / 100 \mathrm{ml}$. The literature on this problem is most confusing, because inhibition has been reported both soon and late after insulin, because different commercial insulins contain different amounts of glucagon, and because the inhibition after insulin may not be due to the hypoglycaemia but may be related to some other change in the internal environment of the cephalic centres or the parietal cells of the stomach.

\begin{tabular}{|c|c|c|c|c|}
\hline Source & Animal & Preparation & $\begin{array}{l}\text { Acid } \\
\text { Output }\end{array}$ & $\begin{array}{l}\text { Comparison of the Effect } \\
\text { of Different Doses of } \\
\text { Insulin on Acid Output } \\
\text { Response }\end{array}$ \\
\hline $\begin{array}{l}\text { Jögi and Uvnäs (1949) } \\
\text { Burstall and Schofield } \\
\text { (1951 a and b and 1953) }\end{array}$ & $\begin{array}{l}\text { Dog } \\
\text { Dog }\end{array}$ & $\begin{array}{l}\text { Gastric fistula } \\
\text { Heidenhain pouch }\end{array}$ & $\begin{array}{l}\text { Peak } \\
\text { Basal }\end{array}$ & $\begin{array}{l}0 \cdot 1-0.2<0 \cdot 5-1 \cdot 0^{1} \\
\text { Depressed by insulin }\end{array}$ \\
\hline $\begin{array}{l}\text { Metys and Ronský (1959) } \\
\text { Hirschowitz and O'Leary } \\
\text { (1964) }\end{array}$ & $\begin{array}{l}\text { Dog } \\
\text { y Dog }\end{array}$ & $\begin{array}{l}\text { Gastric fistula } \\
\text { Gastric fistula }\end{array}$ & $\begin{array}{l}\text { 3-hr } \\
\text { 4-hr } \\
\text { Peak }\end{array}$ & $\begin{array}{l}0.33<0.67>1.33 \\
0.15<0.3>0.6>0.9 \\
0.15>0.3>0.6>0.9 \\
\text { (recalculated) }\end{array}$ \\
\hline $\begin{array}{l}\text { Lee and Thompson (1967) } \\
\text { Lee and Thompson (1969) } \\
\text { Kemp et al (1968) }\end{array}$ & $\begin{array}{l}\text { Rat } \\
\text { Rat } \\
\text { Dog }\end{array}$ & $\begin{array}{l}\text { Pylorus ligated } \\
\text { Gastric fistula } \\
\text { Gastric fistula }\end{array}$ & $\begin{array}{l}\text { 2-hr } \\
\text { 1-hr } \\
\text { Peak }\end{array}$ & $\begin{array}{l}20>40>60>120 \\
0.1>0.2>0.4>0.8>2.0 \\
0.15>0.5>2.0\end{array}$ \\
\hline
\end{tabular}

Table IV Hypoglycaemic inhibition of acid secretion

${ }^{1}$ The symbols $<$ and $>$ compare the acid outputs to the insulin doses shown.

\section{Animal data}

Necheles, Olson, and Morris (1940 and 1941) noticed depression of gastric motility and tone after 0.5-0.7 u/kg Squibb insulin in the dog; this inhibition coincided with very low blood sugars $(10-28 \mathrm{mg} / 100 \mathrm{ml})$, and, as the blood sugar rose to medium and slightly subnormal values, the typical insulin hypermotility appeared. Necheles, Olson, and Scruggs (1942) showed that mild hypoglycaemia from low doses of insulin stimulated gastric secretion from Pavlov pouches; severe hypoglycaemia from higher doses of insulin produced less stimulation; other similar results have been summarized in Table IV.

The simplest explanation for the inhibition of gastric secretion associated with hypoglycaemia was that the low blood glucose directly inhibits parietal cell function as does anoxia (Pickett and van Liere, 1939) analogous to the depression of intestinal enzyme output (Kneller and Nasset, 1949) or colonic motility (Killenberg and Cornwell, 1964) associated with severe hypoglycaemia. Indeed, Jordan and Quintana (1964) were able to inhibit insulin-stimulated gastric secretion by inducing profound hypoglycaemia with a larger dose of insulin; both this hypoglycaemia and the inhibition were still produced if glucagon-free insulin was used, and both were prevented by glucose infusions. Eisenberg, Woodward, Quintana, and Dragstedt (1963) could not prevent insulin inhibition of histamine-stimulated acid by glucose infusion, and therefore suggested that 'a transient hyperkalosis of the parietal cell temporarily interferes with acid elaboration ....

Hirschowitz and his co-workers (Hirschowitz and O'Leary, 1964; Hirschowitz, 1966; Hirschowitz and Sachs, 1967a and b) have systematically studied the inhibitory action on histaminestimulated secretion of large doses of insulin. This inhibition was obtained with glucagon-free insulin, was dose-dependent, associated with a fall in plasma and gastric juice potassium, and not reversed by prevention or correction of the hypoglycaemia, but was reversed or prevented by intravenous potassium chloride or by intravenous rubidium. The inhibition associated with very high doses of insulin in the rat (Lee and Thompson, 1967) and dog (Kemp, Herrera, Tsukamoto, and Eisenberg, 1968b) coincided with depression of blood sugar and serum potassium.

It seems clear from these studies that insulin could both (vagally) stimulate and (peripherally) inhibit gastric secretion. There are two possible experimental methods of confirming this double action of insulin by studying the two effects independently.

First, ruminants (who have no psychic vagal phase of gastric secretion) show only inhibition of gastric acid after insulin with a significant correlation between blood sugar and titratable acidity. This inhibition was unaffected by vagotomy and was therefore. a peripheral effect associated with hypoglycaemia (Hitchcock, 
Karvonen, and Phillipson, 1948). Secondly, a nonhypoglycaemic drug such as 2-D-deoxy-glucose could be used as a vagal stimulant; increasing doses showed no dose-response reversal, and the peak acid output after 2-D-deoxy-glucose was significantly higher than after insulin (Hirschowitz and Sachs, 1965; Eisenberg et al, 1966).

INHIBITION OF GASTRIC SECRETION AFTER INSULIN IN MAN

\section{Initial phase}

Mahler (1930) noted a fall in acid secretion in the first 25 minutes after insulin, attributabte : to a primary inhibitory action of insulin itself. A similar inhibitory phase was also noted by Roholm (1930) after Leo insulin. Olson and Necheles (1953) therefore systematically studied in 15 patients with duodenal ulcer the change in acid after 25 units insulin and found a significant decrease at $\mathbf{3 0}$ minutes compared with pre-insulin acid output. A similar significant reduction was found in the volume, acidity, and acid output at 15 and 30 minutes after regular insulin in 33 healthy subjects (Olsen and Necheles, 1955) and it was thought possible that this inhibition could be due to the glucagon in this insulin.

Aylett (1963) has reviewed the effect of glucagon on gastric secretion in man and animal, having shown (Aylett, 1962) that as little as $2 \mathrm{mg}$ glucagon intravenously would significantly inhibit gastric secretion in response to a water meal and that inhibition was present even if the glucagon was given at the same time as glucagon-free insulin. Aylett agreed that the biphasic action of 'insulin' upon gastric secretion may have been due to the glucagon contamination, and she suggested that 'glucagon-free insulin' should always be used for this test.

The glucagon content of commerical insulin varies considerably, was probably always considerable from the 1920 s to the 1940 s, and may have been responsible for the many previous reports of an early phase of inhibition of gastric secretion after 'insulin'. However, in the last twenty years the manufacturing methods in Britain and Denmark have changed, and these insulins, unlike some American insulins (Rowlinson and Lesford,1951), now contain insignificant amounts of hyperglycaemic factor. In the present studies no significant early inhibitory phase was noted after the Boots insulin, which with other British insulins, as well as Novo insulin, have glucagon concentrations so low (less than $0.01 \%$ ) as to be negligible, and therefore are suitable for the insulin test, as is Lilly crystalline insulin $(0 \cdot 1 \%$ glucagon).

EXTREME HYPOGLYCAEMIA IN MAN

In one patient in the series of Clark et al (1964) a fall in blood glucose of more than $60 \mathrm{mg} / 100 \mathrm{ml}$ (fasting and lowest blood glucose not stated) was associated with relatively low peak acid output after insulin compared with post-histamine acid output.

There are no other reports in the literature of extreme hypoglycaemia being achieved in man in $\overrightarrow{\bar{F}}$ an insulin test, but the results of the present study $\frac{\overrightarrow{0}}{0}$ in which blood glucose concentrations below 15 등 $\mathrm{mg} / 100 \mathrm{ml}$ were associated with decreased acid $\overline{\bar{\sigma}}$ output are entirely compatible with the results in $\mathbb{\nabla}$ animals subject to extreme hypoglycaemia, irrespective of whether the mechanism of inhibi- $\infty$ tion of parietal cell function is by decrease in the $\vec{\circ}$ glucose concentration and/or the potassium $\overrightarrow{\vec{H}}$ concentration in the blood.

CRITERIA FOR AN ADEQUATE INSULIN TEST IN THE UNOPERATED SUBJECT

Obviously, the results in one individual may not $\vec{\circ}$ be taken as representative and further tests with different doses of insulin are needed in many o different subjects. However, the present results suggest that an insulin dose of about $0.2 \mathrm{u} / \mathrm{kg}$ may $\vec{O}$ be optimum in producing sufficient hypoglycaemia (blood glucose below $30 \mathrm{mg} / 100 \mathrm{ml}$ ) to $\frac{0}{0}$

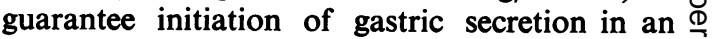
individual, to ensure a near maximum vagal acid $\vec{\varphi}$ output, and to prevent blood glucose falling so $\vec{\partial}$ low (below $15 \mathrm{mg} / 100 \mathrm{ml}$ ) that hypoglycaemic inhibition of gastric secretions or dangerous side effects are produced.

\section{Addendum}

Isenberg, Stening, Ward, and Grossman (1969) gave intravenous injections of insulin (0.025-0.4 $\mathrm{u} / \mathrm{kg}$ ) to five healthy men. Peak 15 -minute acid output was similar after $0 \cdot 1,0 \cdot 2$ and $0.4 \mathrm{u} / \mathrm{kg}$ and highest after $0.2 \mathrm{u} / \mathrm{kg}$. Blood glucoses at $30 \mathrm{~min}$ utes were similar after $0 \cdot 1-0 \cdot 4 \mathrm{u} / \mathrm{kg}$, but no acid/ glucose correlations were made. Stening and Isenberg (1969) gave cats with gastric fistulas 0.03-1 $\mathrm{u} / \mathrm{kg}$ insulin intravenously and found $0.5 \mathrm{u} / \mathrm{kg}$ produced the highest peak 15 -minute acid output.

I am indebted to the Wellcome Trust for their support, and wish to thank Mrs Pope and Mrs Shearman for the performance of the gastric secretory tests, as well as Mr Spencer, Mr Tinker, and Dr Gutierrez for the venous cannulations, and Dr M. Hills for statistical advice; Dr R. Assan (Hôtel-Dieu, Paris) for the immunoassay of the Boots Insulin for glucagon, as well as the Medical Departments of Eli Lilly and Company, Novo Research Institute, and Wellcome Research Laboratories for details of the glucagon content of their insulins.

\section{References}

Aylett, P. (1962). The effects of glucagon and glucagon-free insulin upon gastric secretion in peptic ulcer patients. Clin. Sci., 22, 179-184. 
Aylett, P. (1963). Some effects of glucagon and insulin upon gastric function. M.D. Thesis, London.

Aylett, P. (1965). Effects of tolbutamide upon gastric secretion and emptying. Brit. med. J., 1, 1464-1466.

Bachrach, W. H. (1953). Action of insulin hypoglycaemia on motor and secretory functions of the digestive tract. Physiol. Rev., $33,566-592$.

Bachrach, W. H., and Bachrach, L. B. (1967). Re-evaluation of the Hollander test. Ann. N.Y. Acad. Sci., 140, 915-923.

Baron, J. H. (1962). Discussion on the physiological and clinical assessment of gastric function. Proc. Roy. Soc. Med., 55, 74-75.

Baron, J. H. (1963). Studies of basal and peak acid output with an augmented histamine test. Gut, 4, 136-144.

Baron, J. H. (1968). Is the augmented histamine test obsolete? Gastroenterology, 54, 133-134.

Baron, J. H. (1969). Timing of peak acid output after pentagastrin. Gastroenterology, 56, 641-643.

Brooke, B. N. (1949). The insulin test for vagal section. Lancet, 2, $1167-1170$.

Brooks, F. P. (1967). Central neural control of acid secretion. In Handbook of Physiology, Section 6; Alimentary Canal, vol. II, Secretion, edited by C. F. Code, p. 809. American Physiological Society, Washington D.C.

Burstall, P. A., and Schofield, B. (1951a). An inhibitory component in the gastric response to insulin hypoglycaemia in Heidenhain pouches in dogs. J. Physiol. (Lond.), 115, 19P-20P.

Burstall, P. A., and Schofield, B. (1951b). The influence of insulin hypoglycaemia on pepsin secretion in Heidenhain pouches in dogs. J. Physiol. (Lond.), 115, 72P-73P.

Burstall, P. A., and Schofield, B. (1953). Secretory effects of psychic stimulation and insulin hypoglycaemia on Heidenhain gastric pouches in dogs. J. Physiol. (Lond.), 120, 383-408.

Clark, C. G., Curnow, V. J., Murray, J. G., Stephens, F. O., and Wyllie, J. H. (1964). Mode of action of histamine in causing gastric secretion in man. Gut, 5, 537-549.

Davis, R. A., and Brooks, F. P. (1962). Variability of gastric secretory response to insulin hypoglycemia in fistulous beagle dogs. Amer. J. Physiol., 202, 1070-1072.

Davis, R. A., and Brooks, F. P. (1963). Gastric secretion, continuously recorded blood sugar, and plasma steroids after insulin. Amer. J. Physiol., 204, 143-146.

Davis, R. A., Brooks, F. P., and Robert, C. M. (1965). Gastric secretory response to graded insulin hypoglycaemia. Amer. J. Physiol., 208, 6-8.

Demand, H. A., Gross, H. U., and Berg, G. (1968). Effects of continuous insulin infusions on unstimulated human gastric secretion. Part I. Interrelations between insulin dosage, blood sugar and gastric secretory changes. Part II. Quantitative changes of the gastric juice pattern. Gastroenterology, 54, 1038-1049.

Eisenberg, M. M., Emas, G. S., and Grossman, M. I. (1966). Comparison of the effect of 2-deoxy-D-glucose and insulin on gastric acid secretion in dogs. Surgery, 60,111-117.

Eisenberg, M. M., Woodward, E. R., Quintana, R., and Dragstedt, L. R. (1963). Insulin inhibition of gastric secretion. J. surg. Res., 3, 479-484.

Gillespie, G., Gillespie, I. E., and Kay, A. W. (1969). Response to insulin of the intact stomach in patients with duodenal ulcer. Gut, 10, 744-748.

Hiles, C. H. (1947). Gastric secretory response in hypoglycemia as produced during insulin shock therapy. Amer. J. med. Sci., 214, 667-672.

Hirschowitz, B. I. (1966). Quantitation of inhibition of gastric electrolyte secretion by insulin in the dog. Amer.J. dig. Dis., 11, 173-230.

Hirschowitz, B. I., and O'Leary D. K. (1964). Dose-dependence of insulin-stimulated gastric secretion. Amer. J. dig. Dis., 9, 379-397.

Hirschowitz, B. I., and Sachs, G. (1965). Vagal gastric secretory stimulation by 2-deoxy-D-glucose. Amer. J. Physiol., 209, 452-460.

Hirschowitz, B. I., and Sachs, G. (1967a). Insulin effects on gastric secretion and blood electrolytes modified by injected potassium. Amer. J. dig. Dis., 12, 7-18.

Hirschowitz, B. I., and Sachs, G. (1967b). Insulin inhibition of gastric secretion: reversal by rubidium Amer. J. Physiol., 213, 1401-1405.

Hitchcock, M. W. S., Kárvonen, M. J., and Phillipson, A. T. (1948). The effect of insulin on the acidity of the abosomal contents of lambs. (Abstr.) Acta physiol. scand., 16, Suppl. $53,33-34$.

Hollander, F. (1946). The insulin test for the presence of intact nerve fibres after vagal operations for peptic ulcer. Gastroenterology, 7, 607-614.

Hollander, F., Jemerin, E. E., and Weinstein,V. A. (1942). An insulin test for differentiating vagal from non-vagal stomach pouches. Fed. Proc., 1, 116.

Hubel, K. A. (1966). Insulin-induced gastric acid secretion in young men. Gastroenterology, 50, 24-28.
Ihre, B. (1938). Human gastric secretion. Acta med. scand., Suppl. 95.

Isenberg, J. I., Stening, F., Ward, S., and Grossman, M. I. (1969). Relation of gastric secretory response in man to dose of insulin. Gastroenterology, 57, 395-398.

Jemerin, E. E., Hollander, F., and Weinstein, V. A. (1942). A comparison of insulin and food as stimuli for the differentiation of vagal and non-vagal gastric pouches. Gastroenterology, 1, 500-512.

Jögi, P., Ström. G., and Uvnäs, B. (1949). The origin in the CNS of gastric secretory impulses induced by hypoglycemia. Acta physiol. scand., 17, 212-221.

Jögi, P., and Uvnäs, B. (1949). The gastric secretory response to insulin in dogs and cats. Acta physiol. scand., 17, 206-211.

Jordan, P. M., and Quintana, R. (1964). Insulin inhibition of gastrin stimulated gastric secretion. Gastroenterology, 47, 617-625.

Kalk, H., and Meyer, P. F. (1932). Blutzuckerspiegel und Magensekretion. Z. f.klin. Med., 120, 692-714.

Kemp, D. R., Herrera, F., Isaza, J., and Eisenberg, M. M. (1968a), On the critical nature of blood sugar levels in the vagal stimulation of gastric acid secretion in normal and diabetic dogs. Surgery, 64, 958-966.

Kemp, D. R., Herrera, F., Tsukamoto, M., and Eisenberg, M. M. (1968b). Insulin-potassium effect on gastric acid secretion and antral motility in dogs. Gastroenterology, 54, 190-196.

Killenberg, P. G., and Cornwell, G. G. (1964). Effect of insulin hypoglycemia on the human sigmoid colon. Amer. J. dig. Dis., 9, 221-228.

Kneller, A. W., and Nasset, E. S. (1949). Relationship of insulin hypoglycemia to intestinal secretion. Amer. J. Physiol., 159, 89-94.

Lee, Y. M., and Thompson, P. H. (1967). Dose response of gastric secretion, and electrolyte output in pylorus-ligated rats to insulin hypoglycemia. Experimentia (Basel), 23, 300-302.

Lee, Y. H., and Thompson, J. H. (1969). Response of rats with chronic gastric fistulas to subcutaneous injections of histamine, ICI-50123, and insulin. Amer. J. dig. Dis., 14, 14-29.

Mahler, P. (1930). Beiträge zur Chemie des Menschlichen Magensaftes. Wien. Arch. inn. Med., 19, 413-450.

Makhlouf, G. M. (1968). Measures of gastric acid secretion in man. Gastroenterology, 55, 423-429.

Marks, I. N., Komorav, S. A., and Shay, H. (1960). Maximal acid secretory response to histamine and its relation to parietal cell mass in the dog. Amer. J. Physiol., 199, 579-588.

Metys, J., and Ronsky, R. (1959). Contribution to the action of insulin on gastric secretion. (Czech.) Čs. Gastroent. Výż., $13,95-101$.

Necheles, H., Olson, W. H., and Morris, R. (1940). Effect of hypoglycemia on gastric motility. Amer. J. Physiol., 129, P. 429.

Necheles, H., Olson, W. H., and Morris, R. (1941). Depression of gastric motility by insulin. Amer. J. dig. Dis., 8, 270-273.

Necheles, H., Olson, W. H., and Scruggs, W. (1942). The effect of insulin on gastric secretion. Fed.Proc., 1, 62.

Olson, W. H., and Necheles, H. (1953). Initial depression of human gastric secretion by insulin. Gastroenterology, 24, 362-368.

Olson, W. H., and Necheles, H. (1955). Primary depression of gastric secretion by insulin in normal man. J. Amer. med. Ass., 159, 1013-1014.

Pickett, A. D., and van Liere, E. J. (1939). The effect of anoxia on gastric secretion from Paviov and Heidenhain pouch dogs. Amer. J. Physiol., 127, 637-642.

Roholm, K. (1930). Clinical investigations into the effect of intravenous injection of insulin. IV. Gastric secretion in normal individuals. Acta med. scand., 73, 472-492.

Rowlinson, H. R., and Lesford, J. M. (1951). An in vivo test for the glycogenolytic hyperglycaemic factor in insulin. J. Pharm. Pharmacol., 3, 887-896.

Sharick, P. R., and Campbell, D. A. (1951). Gastric secretory response to insulin hypoglycemia: influence of insulin dosage and blood sugar level. Amer. J. med. Sci., 221, 364-368.

Simici. D., Popesco, M., and Diculesco, G. (1927). L'action de l'insuline sur la sécrétion de l'estomac à l'etat normal et pathologique. Arch. Mal. Appar. dig., 17, 28-43.

Stempien, S. J., Lee, E. R., and Dagradi, A. E. (1968). Clinical appraisal of insulin gastric analysis. Amer. J. dig. Dis., 13, 21-34.

Stening, G. F., and Isenberg, J. I. (1969). Insulin-induced acid secretion after partial vagotomy in dogs and cats. Amer. J. Physiol., 217, 962-964.

Wincey, C., and Marks, V. (1961). A micro-method for measuring glucose using the AutoAnalyzer and glucose-oxidase. $J$. clin. Path., 558-559. 